\title{
EFFECTS OF FOREST EDGE ON PEST CONTROL SERVICE PROVIDED BY BIRDS IN FRAGMENTED TEMPERATE FORESTS
}

\author{
Krisztina Bereczki ${ }^{1 *}$, Katalin Hajdu ${ }^{2 *}$ and András Báldi ${ }^{1}$ \\ ${ }^{1}$ MTA Centre for Ecological Research, Lendület Ecosystem Services Research Group \\ H-2163 Vácrátót, Alkotmány u. 2-4, Hungary; E-mail: bereczki.krisztina@okologia.mta.hu \\ ${ }^{2}$ Faculty of Veterinary Science, Szent Istoán University \\ H-1077 Budapest, Rottenbiller u. 50, Hungary
}

Controlling herbivorous insects by insectivorous birds is one of the most important regulating services in forest ecosystems. The fragmentation of forests and the associated increase of edge effect, however, influences forest bird communities and thereby may have an impact on biological control via the modification of prey-predator interactions. In the present study we aimed to examine how insectivorous bird abundance and their predation on artificial caterpillars were affected by forest edges and vegetation structure in fragmented temperate forests of southwest Hungary. We found an unexpected negative humpedshaped pattern for predation rate as well as for bird abundance, having peaks both at the edge and in the interior ( $50 \mathrm{~m}$ from the edge). We found a positive correlation between bird abundance and predation rate, therefore the important role of birds in insect pest control was supported. Interestingly, the abundance of insectivorous birds had negative relationships to forest structure variables, such as tree basal area and tree species richness. This unexpected pattern may be a result of the context-dependency of edge effects that cannot be fully explained by our study. It highlights the need for more studies to explore the general pattern of edge effect on insect pest control.

Key words: ecosystem service, edge effect, caterpillars, habitat fragmentation, predation, predator-prey interaction.

\section{INTRODUCTION}

Although herbivorous insects are the natural part of forest ecosystems, they are often considered as pests because they provoke severe damage for forestry worldwide every year (ICP FOREST 2011). Thus the natural control of herbivorous insect populations by insectivorous birds is considered to be one of the major ecosystem services provided by biodiversity (SEKERCIOGLU 2006, WeNNY et al. 2011). By consuming herbivorous insects, birds contribute to the regulation of pest populations which may result in the reduction of plant damage (SANZ 2001, Mols \& VISSER 2007). In forest ecosystems, herbivorous insects - especially leaf consuming insects - cause significant stress to the trees resulting in decreased growth and fecundity (Rieske \& Dillaway 2008) as well as increased vulnerability to secondary pests and diseases (JEPSEN $e t$ al. 2013). Thus, the reduction in insect herbivory by forest birds improves the

\footnotetext{
*These authors contributed equally to this paper.
} 
health condition of the trees, favours seedling survival and increases natural regeneration (SimonetTi et al. 2007, BRidgeland et al. 2010, GifFARd et al. 2012). This beneficial role of insectivorous birds in forest health, however, is threatened by habitat loss and fragmentation of forests in good ecological condition (Boulinier et al. 2001, SEKERCiOglu et al. 2002).

Fragmentation of forest habitats involves several components such as reduced patch size and increased edge effects (SAUNDERS et al. 1991, FAHRIG 2003). These components of fragmentation change both abundance and community structure of species remained in the fragments and thereby is expected to alter the intensity of ecological processes involving species interactions, like predation, parasitism or competition (Murcia 1995, Ewers \& Didham 2007). Considering forest bird communities and their ecological functions, fragmentation has been shown to have an array of effects mainly through the increased importance of edge effects (Š́́LEK et al. 2010). Edge effects can be defined as the changes in abiotic and biotic conditions, which occur at the abrupt transition between two adjoining habitats interacting with each other (MurcIA 1995). Forest edges are usually characterized by diverse, bushy vegetation and thereby offer nesting and hiding places for forest birds (SAARIKIVI \& Herczeg 2014), moreover, are expected to increase the abundance of herbivorous insects (BARBER \& MARquis 2011) and thereby further attract insectivorous birds (McCollin 1998). These changes in abundance both of birds and herbivores may result in increased intensity of avian insectivory (GonzÁLEz-Gómez et al. 2006, BARBARo et al. 2014). However, forest edges have been shown to also increase nest predation risk and parasitism rates which can have a strong negative effect on bird population densities (RoBInson et al. 1995, BATÁry \& BÁLdi 2004) and thereby can lead to decreased bird abundance at edges compared to forest interiors (KARANTH et al. 2006). The decreased bird abundance at forest edges, in turn, can disrupt avian insectivory which may result in increased frequency of insect outbreaks. Therefore, there is still no consensus how forest edges influence the interaction between birds and insects that is the pest control service birds provide. Moreover, the location and context dependency of edge effects (RIES \& SISK 2004) further increase the uncertainty. Therefore, a number of studies are needed in different regions and habitats to provide the evidence for a conclusion of general pattern on edge effect on insect pest control.

In the present study we aimed to examine how (i) insectivorous birds as well as (ii) bird predation rate on caterpillars - as the main herbivorous insects of temperate forests - were affected by immediate edges and vegetable structure in a fragmented forest of Central Europe. To examine fine-scale pattern in the interaction between birds and caterpillars from edges to interiors, we sampled four different distances from immediate edges towards forest interiors.

We tested the following hypotheses: (1) Bird predation on caterpillars is higher in immediate forest edges compared to forest interiors. (2) Predation 
rate is positively related to bird abundance. (3) Bird abundance is positively affected by forest edges. (4) The distribution of birds across edges can be explained by the changes in forest vegetation structure. We further presumed that bird abundance as well as predation rate change linearly (on a transformed or untransformed scale) with the growing distance from forest edge.

\section{METHODS}

\section{Study site and design}

The study was conducted in the northern part of the Zselic Hills region, in southwest Hungary in 2013 (Fig. 1). The topography of this region consists of steep slopes and narrow valleys. The average elevation is between $250-350 \mathrm{~m}$. The climate is temperate with a mean annual temperature of $10^{\circ} \mathrm{C}$ and an average annual rainfall of $680-730 \mathrm{~mm}$ (DövéNYI 2010). The significant part of this region is covered by native deciduous forests dominated by beech (Fagus sylvatica L.) and hornbeam (Carpinus betulus L.), while the lowest part of this region is rather a mosaic landscapes, where deciduous forests dominated by turkey oak (Quercus petraea (Matt.) Liebl.) and sessile oak (Q. cerris L.) mixed with meadows and with agricultural areas. In this mosaic landscape, four middle aged (50-70 years) forest stands dominated by turkey and sessile oaks were selected situated next to open areas (meadows

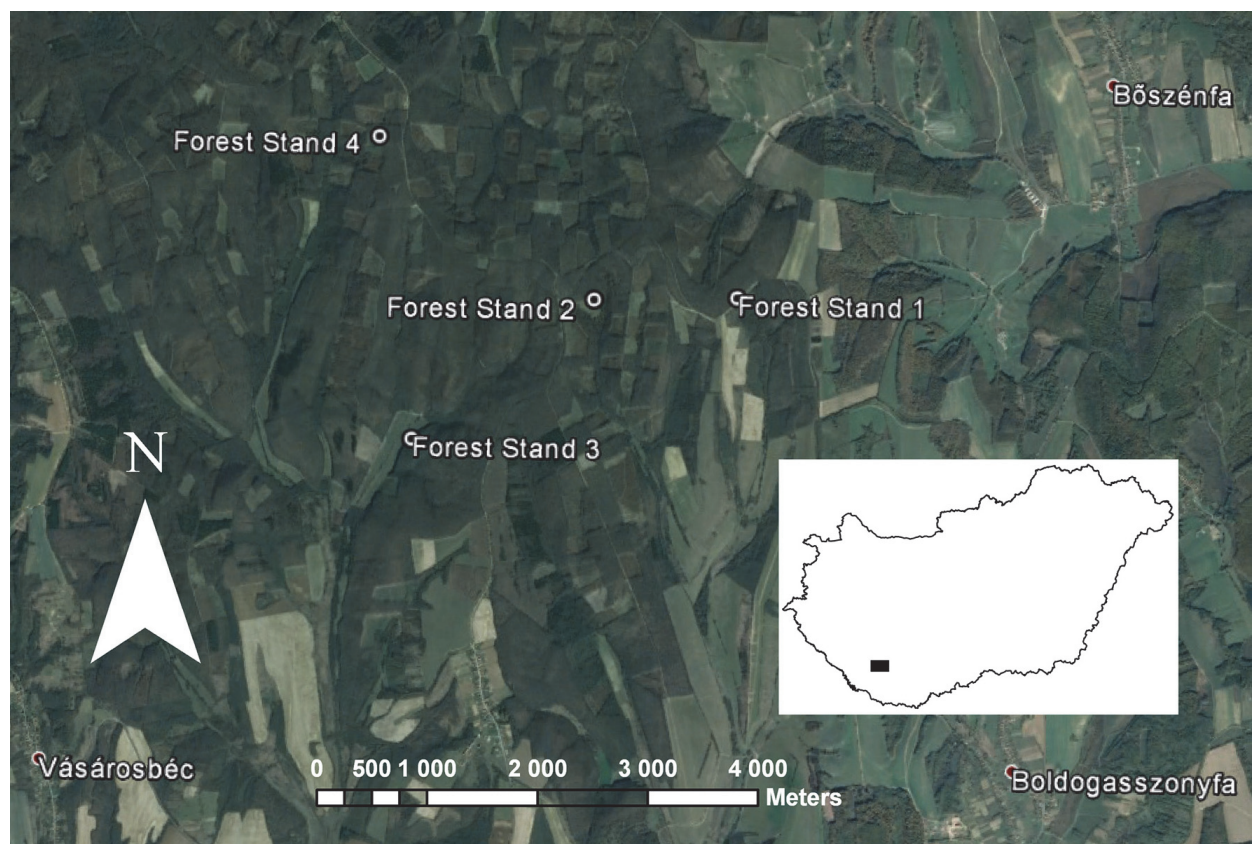

Fig. 1. The location of the study sites. The coordinates of the four sample quadrats are $46^{\circ} 13^{\prime} 14.50^{\prime \prime} \mathrm{N} 17^{\circ} 48^{\prime} 18.89^{\prime \prime} \mathrm{E}$ for forest stand $1 ; 46^{\circ} 13^{\prime} 13.48^{\prime \prime} \mathrm{N} 17^{\circ} 47^{\prime} 18.17^{\prime \prime} \mathrm{E}$ for forest stand $2 ; 46^{\circ} 12^{\prime} 31.86^{\prime \prime} \mathrm{N} 17^{\circ} 46^{\prime} 1.63^{\prime \prime} \mathrm{E}$ for forest stand 3 and $46^{\circ} 14^{\prime} 1.14^{\prime \prime} \mathrm{N} 17^{\circ} 45^{\prime} 45.39^{\prime \prime} \mathrm{E}$ for forest stand 4 
and regeneration areas). The selected stands, characterized by pronounced edge with a total length of at least $100 \mathrm{~m}$, represented the same habitat type and avoided steep slopes $\left(>25^{\circ}\right)$ and water influenced areas. The distance between the selected stands was at least one $\mathrm{km}$.

In the selected forest stands, four transects were laid out parallel to the edge with a total length of $100 \mathrm{~m}$. The distances of transects from the forest edge was the following: 0 $\mathrm{m}, 10 \mathrm{~m}, 25 \mathrm{~m}$ and $50 \mathrm{~m}$. The distance of $50 \mathrm{~m}$ from immediate edge was considered as forest interior based on former studies on edge effect on caterpillar predation (BARBARo et al. 2012, 2014). The $100 \mathrm{~m}$ transects were used for bird survey. For the predation experiment, four sessile oak trees were selected along each transect with a distance of $25 \mathrm{~m}$ among them. For the forest structure assessment, three quadrats were assigned with a size of 10 $\mathrm{m} \times 25 \mathrm{~m}$ (width $\times$ length) at the four sampled distances from immediate edge $(0 \mathrm{~m}, 10 \mathrm{~m}$,

\section{Distance Forest interior \\ from the}

edge
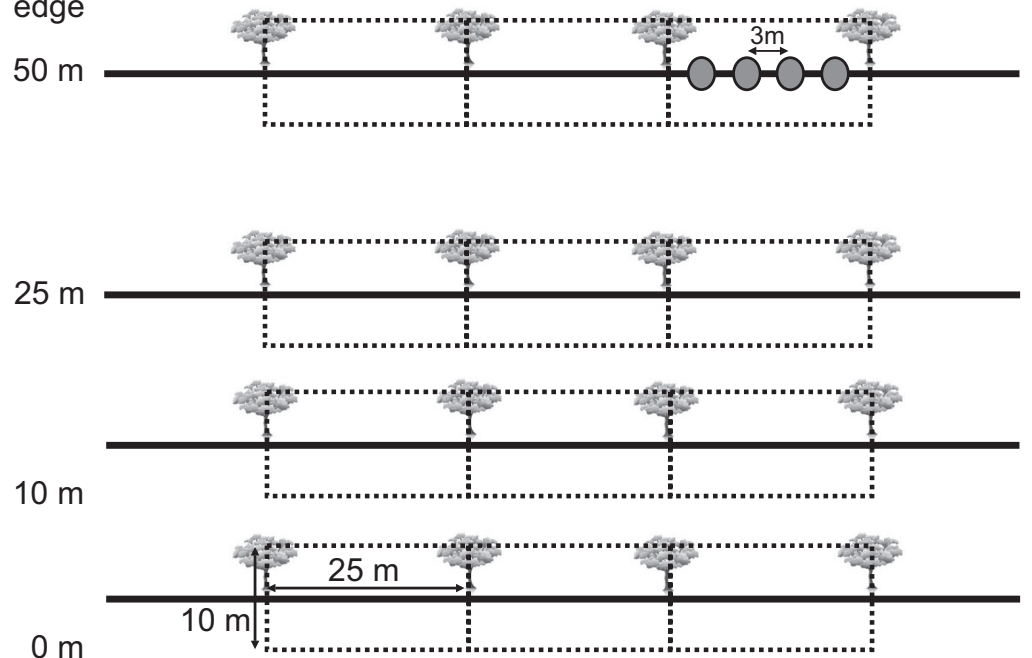

$100 \mathrm{~m}$
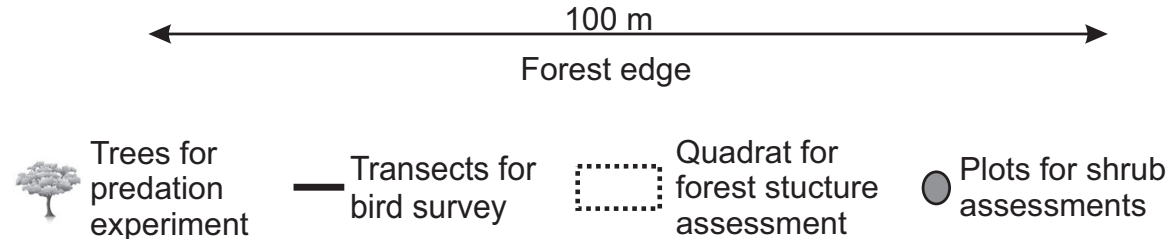

Fig. 2. Study design for the predation experiment on artificial caterpillars, bird survey and forest structure assessment in oak dominated forest stands of Zselic Hills, in Hungary. Predation rate was measured using artificial prey resembling to winter moth (Operophtera brumata L.) larvae attached to the branches of the selected trees. For bird survey, we used a line transect method using four parallel transects at different distances from forest edge. For forest structure assessment, one quadrat was randomly selected among the three quadrats situated along the same transect. Tree species composition and stand structure was estimated in the full size of the quadrats. For shrub assessment, four $1.5 \mathrm{~m}$ circular plots were assigned in every quadrat equally distributed in the longitudinal direction of the quadrats (see upper right corner of the figure). 
$25 \mathrm{~m}$ and $50 \mathrm{~m}$ ). Among the three quadrats situated at the same distance from immediate edge, one quadrat was randomly selected for the forest structure assessment (The detailed study design is shown in Fig. 2).

\section{Predation experiment}

To quantify predation rate of caterpillars by birds, we used artificial prey made by light green plasticine (GonzÁlez-Gómez et al. 2006, Howe et al. 2009, BARbaro et al. 2014) resembling to the fifth instar larvae (length of $25 \mathrm{~mm}$, diameter of $3.5 \mathrm{~mm}$ ) of winter moth (Operophtera brumata L.), which is the most common and abundant folivore species of oaks in the study region (CsóKa 1998) and can cause severe defoliation (TIKKANEN et al. 1998).

On each of the selected trees (see Fig. 2), we attached ten artificial preys with thin metal wires on the external part of the branches near to the leaves at the height of 1.5-2.5 $\mathrm{m}$ ( $\mathrm{n}=40$ preys per transects; $\mathrm{n}=160$ preys per forest plots). Predation rate was measured as the number of caterpillars damaged by predators after a six days period. The six days duration proved to be the optimal prey exposure length (BERECZKI et al. 2014). After field exposure, artificial preys were checked for the signs of predation. We distinguished the beak marks of birds, the parallel teeth marks of small mammals and the chewing marks left by predatory arthropods. The applied method does not provide an accurate estimate of the natural predation rate on caterpillars but it allows us to compare predation pressure among habitats (GonzÁLEz-Gómez et al. 2006) and measure the changes of the predation pressure with the growing distance from the forest edge to the forest interior. The applied plasticine was commercially available, with no harmful effects on animals.

\section{Bird survey}

To estimate bird abundance, we used a line transect method (Gregory et al. 2004) using the four parallel transects with a length of $100 \mathrm{~m}$ (see details above; Fig. 2). Bird sampling was performed in two visits in late May and late June 2013 walked at a low speed of ca. $3 \mathrm{~km} / \mathrm{h}$. All observed or heard individuals were recorded within $5 \mathrm{~m}$ width on each side of the four transects taking care to avoid double counting individuals: we recorded only those individuals situated in front of us. The counting was conducted between $7 \mathrm{am}$ and 11 am on days without rains and heavy wind. Bird abundance was expressed as the total number of recorded individuals per transect. Among the two visits, the maximum abundance of each bird species was considered (BARBARO et al. 2014).

\section{Forest structure assessment}

Forest structure assessment was conducted in one randomly selected quadrat along each transect (see details above; Fig. 2). The main characteristics measured included tree species composition, tree size distribution and shrub density. The stand structure and tree species composition was examined in the full size of the quadrats $(10 \times 25 \mathrm{~m})$. Tree species identity, diameter at breast height $(\mathrm{DBH})$ and basal area of each tree with $\mathrm{DBH}$ larger than $5 \mathrm{~cm}$ were recorded. For shrub assessment four $1.5 \mathrm{~m}$ circular plots were assigned in every quadrat equally distributed in the longitudinal direction of the quadrats with a distance of $3 \mathrm{~m}$ among them. In the circular plots, all individuals of shrub layer including shrub 
Table 1. Results of pairwise correlation analysis between bird abundance and forest structural variables.

\begin{tabular}{llcc}
\hline Dependent variable & Explanatory variable & $\begin{array}{c}\text { Pearson correlation } \\
\text { coefficient }\end{array}$ & $p$ \\
\hline Bird abundance & Number of tree species & -0.278 & 0.026 \\
& Number of tree individuals & -0.031 & 0.811 \\
& Number of shrubs & 0.097 & 0.448 \\
& Mean DBH $(\mathrm{cm})$ & -0.125 & 0.324 \\
& Tree size heterogeneity & -0.188 & 0.136 \\
& Basal area $\left(\mathrm{m}^{2}\right)$ & -0.249 & 0.047 \\
\hline
\end{tabular}

Table 2. The values of Pearson correlation coefficient among forest structural variables.

\begin{tabular}{lcccccc}
\multicolumn{7}{c}{${ }^{*} p<0.05,{ }^{* *} p<0.01,{ }^{* * *} p<0.001$} \\
& $\begin{array}{c}\text { Basal } \\
\text { area }\left(\mathrm{m}^{2}\right)\end{array}$ & $\begin{array}{c}\text { Mean } \\
\mathrm{DBH} \\
(\mathrm{cm})\end{array}$ & $\begin{array}{c}\text { Number } \\
\text { of shrubs }\end{array}$ & $\begin{array}{c}\text { Number } \\
\text { of trees }\end{array}$ & $\begin{array}{c}\text { Number } \\
\text { of tree } \\
\text { species }\end{array}$ & $\begin{array}{c}\text { Tree size } \\
\text { heteroge- } \\
\text { neity }\end{array}$ \\
\hline Basal area $\left(\mathrm{m}^{2}\right)$ & 1 & $0.422^{* *}$ & -0.005 & 0.106 & $0.466^{* * *}$ & $0.499^{* * *}$ \\
Mean DBH $(\mathrm{cm})$ & $0.422^{* *}$ & 1 & $0.326^{* *}$ & $-0.663^{* * *}$ & -0.141 & 0.03 \\
$\begin{array}{l}\text { Number of shrubs } \\
\text { Number of tree }\end{array}$ & -0.005 & $0.326^{* *}$ & 1 & -0.175 & -0.183 & -0.238 \\
$\begin{array}{l}\text { individuals } \\
\text { Number of }\end{array}$ & 0.106 & $-0.663^{* * *}$ & -0.175 & 1 & -0.006 & -0.207 \\
$\begin{array}{l}\text { tree species } \\
\begin{array}{l}\text { Tree size } \\
\text { heterogeneity }\end{array}\end{array}$ & $0.466^{* * *}$ & -0.141 & -0.183 & -0.006 & 1 & $0.631^{* * *}$ \\
\hline
\end{tabular}

species and seedlings above the height of $50 \mathrm{~cm}$ were recorded. The four measurements in the circular plots were combined for the calculation of shrub density (individuals per ha).

\section{Data analysis}

General linear mixed models (GLMM) were built to test the effect of environmental variables on bird abundance, species richness and predation rate of artificial caterpillars (Zuur et al. 2009). The environmental variables were the distance from forest edge and the standardized value of forest structural variables (the number of tree species, the number of tree individuals, the mean diameter at breast height, the tree size heterogeneity, the basal area and the number of shrub species). The forest stand was used as random factor to take into account that four transects were sampled in each fragment. Before modelling, we carried out pairwise correlation analysis and graphical explorations between the dependent and explanatory variables and we checked inter-correlations among forest structural variables (Tables 1 \& 2). Fixed effect selection of the full model was made by backward elimination, during which the maximum likelihood method was used. The random effect was 
tested by restricted maximum likelihood method (FARAwAY 2006). To evaluate collinearity among explanatory variables, variance inflation factor (VIF) was calculated (LIAO \& VALLIANT 2012). During model evaluation the graphical diagnostics of the model (relative weight of samples, normality of residuals and homogeneity of residual variances) were also taken into account in addition to the results of statistics.

The relationship between predation rate and bird abundance were also examined by GLMM. In this case bird abundance was used as fixed and forest stands as random factor. In addition to linear models, multiple comparisons with Tukey post hoc tests were used to reveal the differences among the four distance categories $(0 \mathrm{~m}, 10 \mathrm{~m}, 25 \mathrm{~m}$ and $50 \mathrm{~m})$.

All tests were carried out in R 2.13.0 environment (R Development Core Team 2011). For the linear mixed effects models, we used the packages "nlme" (PInHeiro et al. 2011).

\section{RESULTS}

\section{Predation rate}

The recorded mean predation rate of artificial caterpillars was $19.06 \%$ $(\mathrm{SD}=14.44, \mathrm{n}=65)$, of which $66.42 \%(\mathrm{SD}=1.22, \mathrm{n}=65)$ was bird predation. Mandible marks of chewing arthropods were found on $27.86 \%$ (SD $=7.064, \mathrm{n}$ $=65)$ of artificial preys, $0.32 \%(\mathrm{SD}=$ $0.21, \mathrm{n}=65$ ) of the caterpillars were attacked by small mammals and $3.28 \%$ $(\mathrm{SD}=0.24, \mathrm{n}=65)$ of marks remained unidentified. As the bird predation data gave two-third of all predation, only these data were used in further analyses to assess caterpillar control.

According to the linear models, bird predation rate was not affected by the distance from forest edge (Table 3). Multiple comparisons among the four distances, however, showed significant differences in predation rate: at the distances of 10 and $25 \mathrm{~m}$ from forest edge the predation rate was significantly lower compared both to forest edge and forest interior, while the predation rate of edges and interiors did not differed significantly (Fig. 3). In addition to the distance from the edge, bird predation rate was also correlated with the abundance of insectivorous birds: we found a significant positive correlation

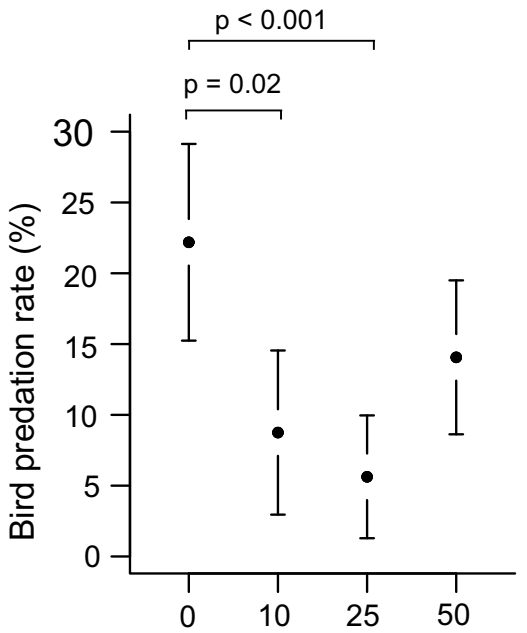

Distance from the edge $(\mathrm{m})$

Fig. 3. The value of bird predation rate (\%) from forest edge to forest interior in oak dominated mosaic landscape of Zselic Hills, in Hungary (mean (+SD)). Multiple comparisons among the four distances (0-10-25-50 $\mathrm{m}$ from edge) were made by Tukey post hoc tests (only the significant differences were indicated). 
Table 3. Results of general linear mixed models (GLMM) testing the effects of the distance from forest edge and the forest structural variables on the bird predation and bird abundance in oak dominated mosaic landscape of Zselic Hills, in Hungary.

\begin{tabular}{llccc}
\hline Dependent variable & Explanatory variable & df & F & $p$ \\
\hline \multirow{2}{*}{ Bird predation } & Distance & 59 & 1.594 & 0.212 \\
& Bird abundance & 59 & 5.968 & $\mathbf{0 . 0 1 5 3}$ \\
\hline \multirow{5}{*}{ Bird abundance } & Distance & 59 & 20.336 & $<\mathbf{0 . 0 0 0 1}$ \\
& Tree species & 59 & 10.011 & $\mathbf{0 . 0 0 2 5}$ \\
& Tree individuals & 59 & 0.057 & 0.811 \\
& Mean DBH & 59 & 0.989 & 0.324 \\
& Tree size heterogeneity & 59 & 2.279 & 0.136 \\
& Basal area & 59 & 4.096 & $\mathbf{0 . 0 4 7}$ \\
& Shrub & 59 & 0.002 & 0.959 \\
\hline
\end{tabular}

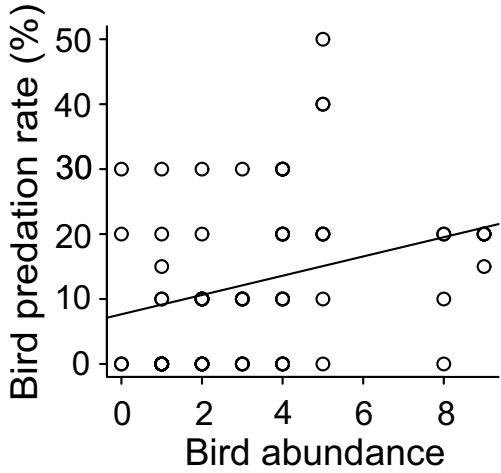

Fig. 4. Relationship between bird predation rate and insectivorous bird abundance. Solid lines represent the line from the generalized linear mixed regression models.

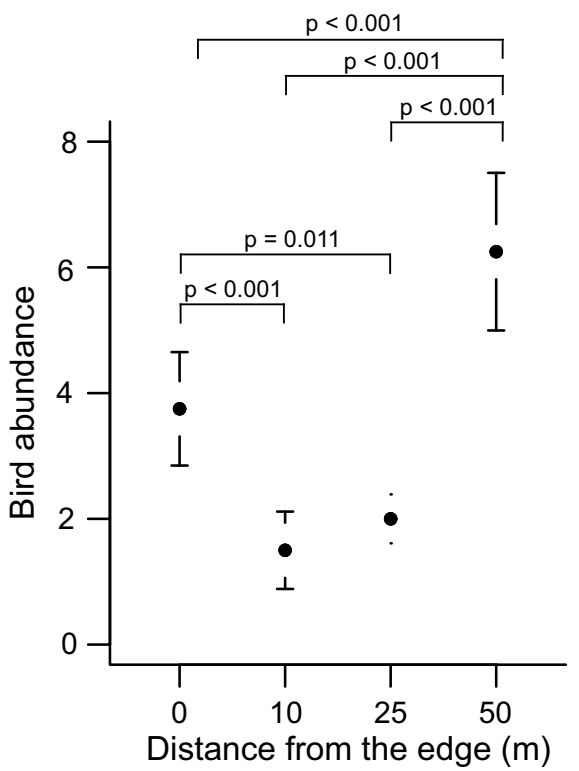

Fig. 5. The abundance of insectivorous birds measured by line transect method (100 m long) from forest edge to forest interior in oak dominated mosaic landscape of Zselic Hills, in Hungary (mean (+SD)). Multiple comparisons among the four distances (0-10-25-50 m from edge) were made by Tukey post hoc tests (only the significant differences were indicated). 
between bird predation rate and abundance of insectivorous birds $(\mathrm{r}=0.296$, $p=0.017$ ) as well as a significant positive effect on bird predation rate (Table 3, Fig. 4).

Table 4. Total abundance of bird species recorded by line transects method at different distances from forest edge in oak dominated mosaic landscape of Zselic Hills, in Hungary.

\begin{tabular}{|c|c|c|c|c|c|}
\hline Species name & Total & $0-10 \mathrm{~m}$ & $10-25 \mathrm{~m}$ & $25-50 \mathrm{~m}$ & $50-75 \mathrm{~m}$ \\
\hline $\begin{array}{l}\text { Great Tit } \\
\text { (Parus major L.) }\end{array}$ & 9 & 2 & 1 & 2 & 4 \\
\hline $\begin{array}{l}\text { Blue Tit } \\
\text { (Parus caeruelus L.) }\end{array}$ & 4 & 2 & - & 1 & 1 \\
\hline $\begin{array}{l}\text { Common Chaffinch } \\
\text { (Fringilla coelebs L.) }\end{array}$ & 15 & 3 & 1 & 4 & 7 \\
\hline $\begin{array}{l}\text { Eurasian Blackcap } \\
\text { (Sylvia atricapilla L.) }\end{array}$ & 6 & 4 & 1 & - & 1 \\
\hline $\begin{array}{l}\text { Common Starling } \\
\text { (Sturnus vulgaris L.) }\end{array}$ & 2 & 2 & - & - & - \\
\hline $\begin{array}{l}\text { Common Chiffchaff } \\
\text { (Phylloscopus collybita L.) }\end{array}$ & 3 & 1 & - & - & 2 \\
\hline $\begin{array}{l}\text { Eurasian Nuthatch } \\
\text { (Sitta europaea L.) }\end{array}$ & 3 & - & - & - & 3 \\
\hline $\begin{array}{l}\text { Middle Spotted Woodpecker } \\
\text { (Dendrocopus medius L.) }\end{array}$ & 2 & 1 & 1 & - & - \\
\hline $\begin{array}{l}\text { Great Spotted Woodpecker } \\
\text { (Dendrocopus major L.) }\end{array}$ & 3 & - & - & 2 & 1 \\
\hline $\begin{array}{l}\text { Black Woodpecker } \\
\text { (Dryocopus martius L.) }\end{array}$ & 1 & 1 & - & - & - \\
\hline $\begin{array}{l}\text { Eurasian Golden Oriole } \\
\text { (Oriolus oriolus L.) }\end{array}$ & 2 & 1 & 1 & - & - \\
\hline $\begin{array}{l}\text { Song Thrush } \\
\text { (Turdus philomelos Brehm) }\end{array}$ & 4 & - & 1 & 1 & 2 \\
\hline $\begin{array}{l}\text { Common Blackbird } \\
\text { (Turdus merula L.) }\end{array}$ & 8 & 2 & - & 1 & 5 \\
\hline $\begin{array}{l}\text { European Robin } \\
\text { (Erithacus rubecula L.) }\end{array}$ & 1 & - & - & 1 & - \\
\hline $\begin{array}{l}\text { Hawfinch } \\
\text { (Coccothraustes coccothraustes L.) }\end{array}$ & 1 & - & 1 & - & - \\
\hline Unidentified & 13 & 5 & 1 & 1 & 6 \\
\hline Total & 77 & 24 & 8 & 13 & 32 \\
\hline
\end{tabular}




\section{Bird community}

We recorded a total of 15 bird species from the four study sites, of which 14 species were insectivorous, i.e. potential predators of caterpillars. The mean abundance of insectivorous birds was $3.38(\mathrm{SD}=2.50, \mathrm{n}=16)$ individuals per transects and the mean species richness was $2.75(\mathrm{SD}=1.69, \mathrm{n}=16)$ insectivorous species per transects. The most abundant species were the Common Chaffinch (Fringilla coelebs L.), the Great Tit (Parus major L.) and the Common Blackbird (Turdus merula L.) (see Table 4).

Abundance of insectivorous birds changed significantly with distance from forest edge (Table 3), but this changing was not linear. Multiple comparisons among the four distances showed that the abundance was the highest in forest interiors and the lowest at the distances of $10 \mathrm{~m}$ from forest edge (Fig. 5). Edges maintained higher bird abundance than the distances of 10 and 25 $\mathrm{m}$ from forest edge, but lower than forest interiors (Fig. 5). In addition to the distance from forest edges, forest structure also affected insectivorous birds: general linear mixed models (GLMM) revealed a significant negative effect of the number of tree species (Table 3, Fig. 6a) and of the basal area (Table 3, Fig. $6 \mathrm{~b}$ ) on bird abundance (Number of tree species: $\mathrm{r}=-0.278$; Basal area: $\mathrm{r}=$ -0.249 ). The value of the variance inflation factor (VIF) was 1.278 indicating that multicollinearity is not an issue in the model. The number of tree species as well as basal area changed significantly with distance from forest edge (one-way ANOVA, number of tree species: $\mathrm{F}_{59}=6.356, p=0.0008$, Fig. $7 \mathrm{a}$; basal area: $\mathrm{F}_{59}=4.470, p=0.0067$, Fig. $\left.7 \mathrm{f}\right)$. In addition to these structural variables, the number of tree individuals (one-way ANOVA, $\mathrm{F}=4.563, p=0.006$; Fig. $7 \mathrm{~b})$ as well as the mean diameter at breast height was affected by the distance
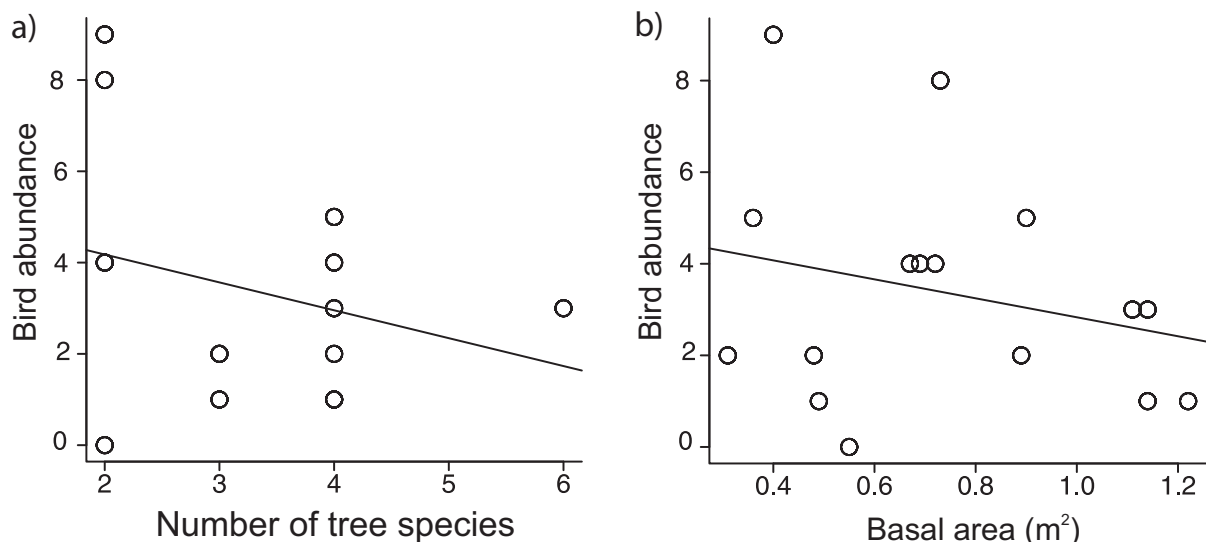

Fig. 6. Relationship between bird abundance and tree species richness $(r=-0.278, p=0.026)$ (a) as well as between bird abundance and basal area $(r=-2.489, p=0.047)(b)$. Solid lines represent the line from the general linear mixed models. 

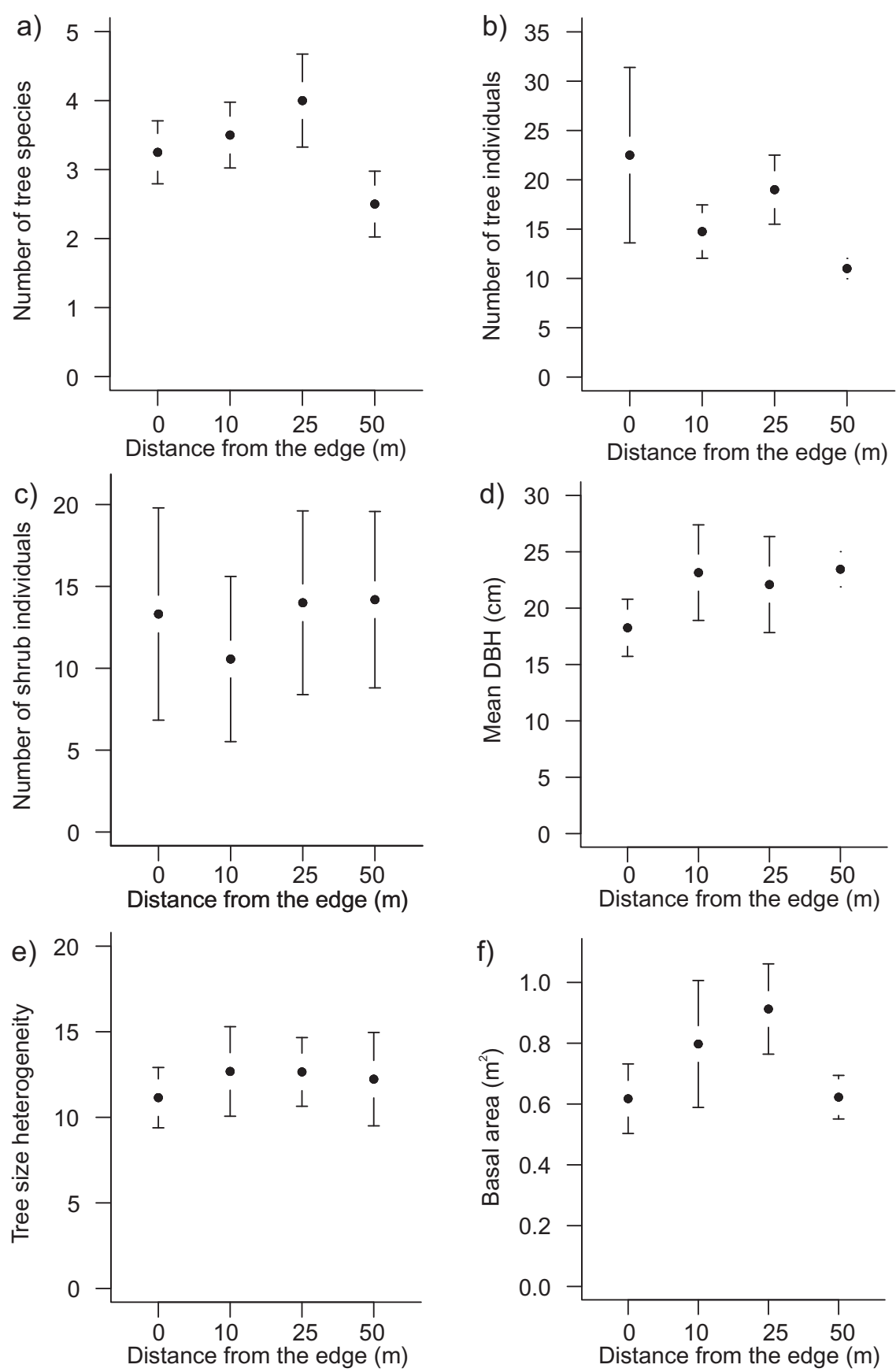

Fig. 7. The value of forest structural variables from forest edge to forest interior in oak dominated mosaic landscape of Zselic Hills, in Hungary. 
from forest edge (one-way ANOVA, $\mathrm{F}=2.312, p=0.0851$; Fig. $7 \mathrm{~d}$ ), but these variables had no effect on bird abundance (Table 3 ).

\section{DISCUSSION}

We found a positive correlation between bird abundance and predation rate, therefore an indirect evidence of bird's role in insect pest control was provided in accordance with our hypothesis and other studies (e.g. GonzÁLEzGómez et al. 2006, BereczKi et al. 2014). We also found an unexpected humpedshaped pattern both in predation rate and bird abundance, having peaks both at the edge and in the interior $(50 \mathrm{~m})$, while significantly lower in between. This negative humped-shaped pattern implies that examining one edge and one interior plot is not always enough to show the effect of immediate edge on species interactions. In our case, comparing only edges and interiors, no significant difference was shown in bird predation rate, however the lower values at the distances of 10 and $25 \mathrm{~m}$ clearly indicates the effect of immediate edge on bird predation. Contrary to our experiment, numerous former studies on edge effect on bird predation rate compared only edges and interiors and got different results. Кон and Menge (2006), for example, found no edge effect on caterpillar predation rate by insectivorous birds in neotropical forest fragments, while other studies mainly from the tropics and the southern hemisphere documented a positive edge effect on avian insectivory (e.g. GonzÁlez-Gómez et al. 2006, Skoczylas et al. 2007, Barbaro et al. 2012, BARBARO et al. 2014).

Contrary to our expectations, the distribution pattern of birds across edges can not be explained by the changes in forest structure from edges to interiors. Interestingly, the abundance of birds had negative relationships to forest structure parameters, usually found as positive predictors for abundance, like number of tree species (e.g. LaIolo 2002), or basal area, a measure of tree cover (e.g. LAwLER \& Edwards 2002). Furthermore, in our case shrub cover had no significant effect on bird abundance contrary to other studies examining the explanatory variables of bird distribution patterns across edges (BERRY 2001, BATÁRY et al. 2014). We may conclude that this is due to the local context-dependency of edge effects. However, the significant positive correlation between bird abundance and predation rate may indirectly indicates that the distribution of birds follow the distribution of food items as it has been often documented in the literature (e.g. Mantyla et al. 2008). Thus, the resource distribution can be an explanation for the bird abundance across edges and interiors. However, in this case an unidentified resource component may cause the unexpected pattern. 
Finally, it should be mentioned that although our study provided an exciting novel result on an unexpected edge effect, our experimental design resulted in methodological doubts which need to be addressed by future studies. For example, there was a potential overlap between transects in the edge and at $10 \mathrm{~m}$ distance related to bird survey. However, our study was conducted during caterpillar peak, when the average search time of birds is ca. $40 \%$ lower than before and after the peak (Naef-Daenzer \& Keller 1999), i.e. birds move smaller distances to forage. Based on our results, we propose new studies addressing the unanswered questions emerged from this research. For example, to avoid double counting of individuals, bird census should be complemented by foraging behavioural studies, use of radio transmitter on individuals, videorecording or mistnetting birds. Furthermore, to better understand the pattern of bird predation from edges to interiors, future studies needs to examine the fine-scale changes in herbivorous insect densities in addition to insectivorous birds. Also, the inclusion of more forest habitat types is needed to check if these results are general across habitats.

One of the reasons for the study was to add evidence for the debate on the effect of forest edges on the interaction between birds and insects. Our results show that context-dependence indeed get into a situation that cannot be fully explained by available knowledge. We provided evidence - in line with other studies from Central Europe (e.g. Diaz 2008, BereczKi et al. 2014) and beyond (e.g. GonzÁlez-Gómez et al. 2006) - that forests management regimes supporting high bird abundance can be an effective way to control insect pest population.

Acknowledgements - We are indebted to two anonymous reviewers for their constructive comments. We thank the foresters and private land owners for allowing use of the study sites. We would like to thank O. Pintér and G. Svéda for their help in the assignment of the study sites and facilitating our field work, Gy. Kovács and N. T. Major for their help in field work. The study was financially supported by the "Lendület" project of the Hungarian Academy of Sciences (LP2011_014).

\section{REFERENCES}

Barbaro, L., Brockerhoff, E. G., Giffard, B. \& van Halder, I. (2012) Edge and area effects on avian assemblages and insectivory in fragmented native forests. Landscape Ecology 27: 1451-1463. doi: 10.1007/s10980-012-9800-x

Barbaro, L., Giffard, B., Charbonnier, Y., van Halder, I. \& Brockerhoff, E. G. (2014) Bird functional diversity enhances insectivory at forest edges: a transcontinental experiment. Diversity and Distributions 20: 149-159. doi: 10.1111/ddi.12132

BARber, N. A. \& MARquis, R. J. (2011) Light environment and the impacts of foliage quality on herbivorous insect attack and bird predation. Oecologia 166: 401-409. doi: 10.1007/ s00442-010-1840-9 
BatÁry, P. \& BÁldi, A. (2004) Evidence of an edge effect on avian nest success. Conservation Biology 18: 389-400. doi: 10.1111/j.1523-1739.2004.00184.x

Batáry, P., Fronczek, S., Normann, C., Scherber, C. \& Tscharntke, C. (2014) How do edge effect and tree species diversity change bird diversity and avian nest survival in Germany's largest deciduous forest? Forest Ecology and Management 319: 44-50. doi: 10.1016/j.foreco.2014.02.004

BereczKi, K., Ódor, P., CsóKa, Gy. \& BÁldi, A. (2014) Effects of forest heterogeneity on the efficiency of caterpillar control service provided by birds in temperate oak forests. Forest Ecology and Management 327: 96-105. doi: 10.1016/j.foreco.2014.05.001

BERry, L. (2001) Edge effects on the distribution and abundance of birds in a southernVictorian forest. Wildlife Research 28: 239-245. doi: 10.1071/WR00057

Boulinier, T., Nichols, J. D., Hines, J. E., Sauer, J. R., Flather, C. H. \& Pollock, K. H. (2001) Forest fragmentation and bird community dynamics: inference at regional scales. Ecology 82: 1159-1169. doi: 10.1890/0012-9658(2001)082[1159:FFABCD]2.0. $\mathrm{CO} ; 2$

Bridgeland, W. T., Beier, P., Kolb, T. \& Whitham, T. G. (2010) A conditional trophic cascade: Birds benefit faster growing with strong links between predators and plants. Ecology 91: 73-84. doi: 10.1890/08-1821.1

CsóKa, Gy. (1998) Oak defoliating insects in Hungary. Pp. 334-335. In: McManus, M. L. \& Liebhold, A. M. (eds): Proceedings: Population dynamics, impacts and integrated management of forest defoliating insects. USDA Forest Service General Technical Report NE247.

Diaz, L. (2008) Influences of forest type and forest structure on bird communities in oak and pine woodlands in Spain. Forest Ecology and Management 223: 54-65. doi: 10.1016/j. foreco.2005.10.061

DövÉNYI, Z. (2010) Magyarország kistájainak katasztere. (Cadastre of Hungarian regions.) MTA Földrajztudományi Kutatóintézet, Budapest, 522-526 pp.

Ewers, R. M. \& Didham, R. K. (2007) The effect of fragment shape and species' sensitivity to habitat edges on animal population size. Conservation Biology 21: 926-936. doi: 10.1111/j.1523-1739.2007.00720.x

FAHRIG, L. (2003) Effects of habitat fragmentation on biodiversity. Annual Review of Ecology, Evolution, and Systematics 34: 487-515. doi: 10.1146/annurev.ecolsys.34.011802.132419

Faraway, J. J. (2006) Extending the Linear Model with R. Chapman and Hall, London, pp. 169-203.

Giffard, B., Corcket, E., Barbaro, L. \& Jactel, H. (2012) Bird predation enhances tree seedling to insect herbivores in contrasting forest habitats. Oecologia 168: 415-424. doi: 10.1007/s00442-011-2089-7

González-Gómez, P. L., Estades, C. F. \& Simonetti, J. A. (2006) Strengthened insectivory in a temperate fragmented forest. Oecologia 148: 137-143. doi: 10.1007/s00442-005-0338-3

Gregory, R. D., Gibbons, D. W. \& Donald, P. F. (2004) Bird census and survey techniques. Pp. 17-56. In: Sutherland, W. J., Newton, I. \& Green, R. E. (eds): Bird ecology and conservation - A handbook of techniques. Oxford University Press, Oxford, USA. doi: 10.1093/acprof:oso/9780198520863.003.0002

Jepsen, J. U., Biuw, M., Ims, R. A., Kapari, L., Schott, T., Vindstad, O. P. L., Hagen, S. B. (2013) Ecosystem impacts of a range expanding forest defoliator at the forest-tundra ecotone. Ecosystems 16: 561-575. doi: 10.1007/s10021-012-9629-9

Howe, A., Lövei, G. L. \& NachmanN, G. (2009) Dummy caterpillars as a simple method to assess predation rates on invertebrates in a tropical agroecosystem. Entomologia Experimentalis et Applicata 131: 325-329. doi: 10.1111/j.1570-7458.2009.00860.x 
ICP Forest (2011) The condition of forests in Europe. Executive Report. Institute for World Forestry, Hamburg, 26 pp.

Karanth, K. K., Nichols, J. D., Sauer, J. R. \& Hines, J. E. (2006) Comparative dynamics of avian communities across edges and interiors of North American ecoregions. Journal of Biogeography 33: 674-682. doi: 10.1111/j.1365-2699.2005.01392.x

Кон, L. P. \& Menge, D. N. L. (2006) Rapid assessment of Lepidoptera predation rates in neotropical forest fragments. Biotropica 38: 132-134.

LAIOLO, P. (2002) Effects of habitat structure, floral composition and diversity on a forest bird community in north-western Italy. Folia Zoologica 51: 121-128.

Lawler, J. J. \& Edwards Jr., T. C. (2002) Composition on cavity-nesting bird communities in montane aspen woodland fragments: the roles of landscape context and forest structure. Condor 104: 890-896. doi: 10.1650/0010-5422(2002)104[0890:COCNBC]2.0. $\mathrm{CO} ; 2$

Liao, D. \& Valliant, R. (2012) Variance inflation factors in the analysis of complex survey data. Survey Methodology 38: 53-62.

Mantyla, E., Alessio, G. A., Blande, J. D., Heijari, J., Holopainen, J. K., Laaksonen, T., Piirtola, P. \& Klemola, T. (2008) From plants to birds: higher avian predation rates in trees responding to insect herbivory. PLoSOne 3: e2832. doi: 10.1371/journal. pone. 0002832

McCollin, D. (1998) Forest edges and habitat selection in birds: a functional approach. Ecography 21: 247-260. doi: 10.1111/j.1600-0587.1998.tb00562.x

Mols, C. M. M. \& Visser, M. E. (2007) Great tits (Parus major) reduce caterpillar damage in commercial apple orchards. PLoSOne 2, e202 doi: 10.1371/journal.pone.0000202

Murcia, C. (1995) Edge effects in fragmented forests: implications for conservation. Trends in Ecology and Evolution 10: 58-62. doi: 10.1016/S0169-5347(00)88977-6

NAef-DAenzer, B. \& Keller, L. (1999) The foraging performance of great and blue tits in relation to caterpillar development and its consequences for nestling growth and fledging weight. Journal of Animal Ecology 68: 708-718. doi: 10.1046/j.1365-2656.1999.00318.x

Pinheiro, J., Bates, D., Debroy, S. \& Sarkar, D. (2011) The R Development Core Team. nlme: linear and nonlinear mixed effects models. R package version 3: 1-102.

R Development Core Team (2011) $R$ : a language and environment for statistical computing. $R$ Foundation for Statistical Computing. Vienna. http://www.R-project.org/

Rieske, L. K. \& Dillaway, D. N. (2008) Response of two oak species to extensive defoliation: tree growth and vigor, phytochemistry, and herbivore suitability. Forest Ecology and Management 256: 121-128. doi: 10.1016/j.foreco.2008.04.015

RiEs, L. \& Sisk, T. D. (2004) A predictive model of edge effects. Ecology 85: 2917-2926. doi: $10.1890 / 03-8021$

Robinson, S. K., Thomson III, F. R., Donovan, T. M., Whitehead, D. R. \& FaAborg, J. (1995) Regional forest fragmentation and the nesting success of migratory birds. Science 267: 1987-1990. doi: 10.1126/science.267.5206.1987

SAArikivi, J. \& Herczeg, G. (2014) Do hole-nesting passerine birds fare well at artificial suburban forest edges? Annales Zoologici Fennici 51: 488-494. doi: 10.5735/086.051.0603

ŠáleK, M., Svobodová, J. \& Zasadil, P. (2010) Edge effect of low-traffic forest roads on bird communities in secondary production forests in central Europe. Landscape Ecology 25: 1113-1124. doi: 10.1007/s10980-010-9487-9

SANZ, J. J. (2001) Experimentally increased insectivorous bird density results in a reduction of caterpillar density and leaf damage to Pyrenean oak. Ecological Research 16: 387-394. doi: 10.1046/j.1440-1703.2001.00403.x 
Saunders, D. A., Hobbs, R. J., Margules, C. R. (1991) Biological consequences of ecosystem fragmentation: a review. Conservation Biology 5:18-32. doi: 10.1111/j.1523-1739.1991. tb00384.x

SeKercioglu, C. H. (2006) Increasing awareness of avian ecological function. Trends in Ecology and Evolution 21: 464-471. doi: 10.1016/j.tree.2006.05.007

Sekercioglu, C. H., Ehrlich, P. R., Daily, G. C., Aygen, D., Goehring, D. \& Figeroa-Sandí, R. (2002) Disappearance of insectivorous birds from tropical forest fragments. Proceedings of the National Academy of Sciences of the United States of America 99: 263-267. doi: 10.1073/pnas.012616199

Simonetti, J. A., Grez, A. A., Gelis-Diez, J. L. \& Bustamante, R. O. (2007) Herbivory and seedling performance in a fragmented temperate forest of Chile. Acta Oecologica 32: 312-318. doi: 10.1016/j.actao.2007.06.001

Skoczylas, D. R., Muth, N. Z. \& Niesenbaum, R. A. (2007) Contribution of insectivorous avifauna to top down control of Lindera benzoin herbivores at forest edge and interior habitats. Acta Oecologica 32: 337-342. doi: 10.1016/j.actao.2007.06.006

Tikkanen, O. P., Roininen, H., Niemela, P., Tahvanainen, J. \& Zinovjev, A. (1998) Use of host plants by Operophtera brumata L. (Lep., Geometridae) during the first recorded outbreak in the subcontinental boreal zone of Fennoscandia. Journal of Applied Entomology 122: 247-253. doi: 10.1111/j.1439-0418.1998.tb01491.x

Wenny, D. G., DeVault, T. L., Johnson, M. D., Kelly, D., Sekercioglu, C. H., Tomback, D. F. \& Whelan, C. J. (2011) The need to quantify ecosystem services provided by birds. The Auk 128:1-14. doi: 10.1525/auk.2011.10248

Zuur, A. F., Ieno, E. N., Walker, N. J., Saveliev, A. A. \& Smith, G. (2009) Mixed effects models and extension in ecology with R. Springer, New York, 574 pp., doi: 10.1007/978$0-387-87458-6$

Revised version received February 11, 2015, accepted June 6, 2015, published August 14, 2015 